\title{
OPTIMALISASI USAHA TERNAK LELE DAN AYAM PEDAGING MELALUI PEMELIHARAAN YANG INTENSIF
}

\author{
Lena Walunguru $^{1)}$, Marsema Kaka Mone ${ }^{2)}$ \\ 1) Jurusan TPH Politeknik Pertanian Negeri Kupang \\ Email : walungurulena@yahoo.com \\ ${ }^{2)}$ Jurusan TPH Politeknik Pertanian Negeri Kupang \\ Email : sema_tph@yahoo.co.id
}

\begin{abstract}
Abstrak
Kelompok Inaie dan Berkat berlokasi di RT 26 RW 09, Kelurahan Fontein, Kota Kupang. Kelompok Inaie beternak/pembesaran lele dan Kelompok Berkat beternak ayam. Dalam kegiatan beternak kelompok menghadap masalah yaitu pengetahuan dan ketrampilan kelompok dalam beternak lele dan ayam terbatas; tingkat kematian lele dan ayam tinggi; belum mengetahui cara membuat pakan ikan dan ransum ayam; peralatan makan dan minum ayam terbatas, tidak ada peralatan untuk membuat pakan ikan, ransum ayam, mengukur jumlah pakan/ransum; populasi ternak terbatas karena kolam dan kandang tidak memadai; dan belum melakukan manajemen pakan dan ransum, pencegahan penyakit pada ternak, serta pencatatan usaha.

Kegiatan Ipteks bertujuan kelompok Inaie dan Berkat mempunyai pengetahuan dan ketrampilan yang baik dan benar dalam beternak (ikan lele dan ayam) didukung sarana dan prasarana penunjang dan melakukan manajemen usaha agar produksi meningkat. Target kegiatan adalah kelompok dapat menerapkan Ipteks yang menjadi solusi bagi masalah-masalah yang dihadapi dalam beternak, sehingga berdampak terhadap pendapatan melalui peningkatan hasil dan menjadi usaha yang mandiri dan produktif secara ekonomis. Target dicapai melalui kelompok mempunyai pengetahuan dan ketrampilan beternak (pembesaran) ikan lele dan ayam secara baik dan benar; meminimalkan kematian ikan dan ayam melalui sterilisasi bibit ikan dan memvaksin ayam; menjaga kebersihan kandang dan kolam (sebelum dan sesudah digunakan) dan menggunakan air bersih dan menjaga kebersihaannya dari kotoran-kotoran; membuat ransum ayam dan pakan ikan; menyediakan tempat makan dan minum air yang lebih memadai; populasi ternak ditingkatkan melalui pembuatan kandang dan kolam yang memadai; serta melakukan manajemen pakan ikan, pencegahan penyakit, dan pembukuan sederhana usaha ternak ikan lele dan ayam.

Berkaitan dengan hal tersebut diatas, maka peternak perlu mendapat pembelajaran dengan materi yang berkaitan dengan masalah-masalah dalam beternak. Pembelajaran disampaikan dengan metode ceramah dan diskusi; demonstrasi; praktik; rancang bangun; demplot; dan pendampingan. Pembelajaran dilaksanakan dalam bentuk kegiatan yang direncanakan dengan tahapan sosialisasi; persiapan alat dan bahan; pelaksanaan berupa penyampaian materi; pembuatan peralatan penunjang, dan demplot; monitoring dan evaluasi; serta pembuatan laporan akhir dan publikasi ilmiah.
\end{abstract}

Kata Kunci: Beternak/pembesaran ikan lele, beternak ayam pedaging, serta mandiri dan produktif secara ekonomi

\section{PENDAHULUAN}

Kelompok Inaie dan Berkat terbentuk pada tahun 2014, berlokasi di RT 26 RW 09 Kelurahan Fontein. Kelompok Inaie anggotanya berjumlah 10 orang dan kelompok Berkat berjumlah 8 orang. Anggota kedua ini setelah melaksanakan tugasnya (sebagai pegawai dan kegiatan rumah tangga) memanfaatkan waktu untuk beternak (ayam dan ikan lele), dan beberapa bertani (bertanam sayuran seperti sawi, kangkung, dan tomat) di pekarangan. Kegiatan beternak dan bertani dilakukan guna mendukung kebutuhan rumah tangga.

Anggota kedua kelompok terutama yang beternak berkemauan agar usahanya menjadi produktif untuk mendukung perekonomian rumah tangga. Hal ini didukung dengan tersedia pekarangan untuk beternak (setiap anggota mempunyai pekarangan dengan luas rata-rata 100 $200 \mathrm{~m}^{2}$ ), kondisi pekarangan relatif teduh (cocok untuk beternak ayam dan ikan lele), tersedia cukup air (tempat tinggal anggota kelompok dekat dan dialiri sumber air bersih sepanjang tahun, terdapat sungai yang tidak pernah kering, dan beberapa rumah anggota mempunyai sumur), dan tersedia pasar untuk menjual hasil ternak (dekat dengan warung-warung makanan dengan menu ayam dan ikan lele). Disamping itu anggota berkemauan untuk belajar dan mempunyai ketrampilan beternak (ayam dan ikan lele) serta mempunyai waktu menjalankan usaha.

Kelompok Inaie beternak ikan yaitu pembesaran lele, dilakukan 1-2 kali setiap tahunnya dengan masa produksi \pm 3 bulan. Bibit ikan dibeli dari peternak di Bakunase atau Noekele dengan harga Rp. 1.500/ekor. Ikan diberi pakan toko yang dibeli Rp. 13.000/kg. Setiap produksi membutuhkan biaya pakan \pm Rp. 325.000 .

Ikan dibudidaya dalam kolam terpal atau kolam permanen. Umumnya setiap anggota mempunyai satu kolam (80\% kolam terpal dan $20 \%$ kolam permanen), rata-rata berukuran 2-3 x 1-2 x $0,5 \mathrm{~m}$ (pxlxt). Jumlah lele yang dipelihara setiap produksi \pm 200 ekor (kolam terpal) atau \pm 300 ekor (kolam permanen). Sedikitnya jumlah bibit lele yang dipelihara disebabkan beberapa pertimbangan yaitu 
tingkat kematian bibit yang cukup tinggi (dapat mencapai $40 \%$ ), biaya membeli pakan cukup tinggi, dan ukuran kolam terutama terpal luasnya terbatas karena terpal yang digunakan umumnya sudah lama dimana banyak bagian yang robek/berlubang.

Ikan dipelihara sekedarnya sebatas pengetahuan, ketrampilan, serta ketersediaan sarana prasarana. Kolam tidak dibersihkan dari kotorankotoran sebelum atau sesudah digunakan dan tidak mengganti air kolam sisa penggunaan sebelumnya. Kolam yang tidak bersih dan kualitas air yang jelek menjadi potensi timbulnya penyakit non parasit. Bibit yang dibeli langsung dimasukkan dalam kolam, tanpa perlakuan pencegahan penyakit sebelum ditebar ke kolam yang dapat menyebabkan ikan mudah terserang penyakit. Kelompok mendapatkan adanya serangan penyakit kulit bintik putih (white spot) disebabkan infeksi jamur pada kulit dan borok karena infeksi sekunder bakteri. Serangan penyakit berpengaruh menurunkan hasil panen (mencapai 30-40\%).
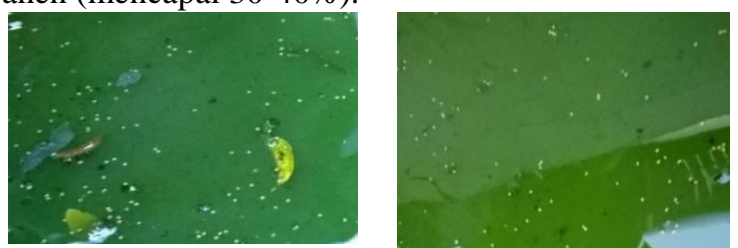

Gambar 1. Kolam Ikan Tidak Bersih, Air yang Kotor, dan Pakan Ikan Diberi Berlebih

Kelompok beranggapan bahwa kegiatan budidaya ikan yang terpenting adalah pemberian pakan, namun tidak mengatur jumlah dan waktu pemberian pakan. Kondisi ini menyebabkan pakan ikan yang diberi sering berlebih, mereka berangapan bahwa pakan yang berlebih akan dimakan ikan pada waktu berikutnya, padahal pakan yang tidak dikonsumsi akan terendap di dasar kolam yang akan menurunkan kualitas air. Disamping itu dalam kondisi anaerob sisa pakan akan terurai menghasilkan amoniak yang bersifat racun, sehingga dapat menyebabkan kematian ikan.

Pakan berlebih merupakan pemborosan, sebaliknya bila tidak cukup menyebabkan kebutuhan nutrisi ikan tidak terpenuhi sehingga ketahanan tubuh rendah (mudah sakit). Pakan ikan diberikan tiga kali sehari (pagi, siang, dan sore), tetapi banyaknya pakan yang diberikan tidak ditimbang, karena kelompok tidak mengetahui bagaimana menghitung kebutuhan pakan juga tidak tersedia peralatan (timbangan dan wadah). Kelompok merasa biaya pembelian pakan cukup besar, padahal biaya dapat dikurangi bila dilakukan pengaturan pemberian pakan (jumlah dan waktu) dan membuat pakan ikan sendiri. Untuk itu Kelompok Inaie menyadari bahwa mereka perlu mempunyai pengetahuan dan ketrampilan dalam teknis pembesaran ikan lele, mengatur kebutuhan pakan ikan, dan dapat membuat pakan ikan (didukung oleh bahan-bahan pakan ikan tersedia setiap saat di pasar dan harganya murah).

Kelompok Berkat beternak ayam pedaging, dilakukan di pekarangan rumah masing-masing. Bibit ayam dibeli dari toko seharga Rp. 5.000/ekor. Setiap anggota umumnya memelihara sebanyak \pm 25-35 ekor ayam pedaging, dilakukan 1-2 kali setahun dengan masa pemeliharaan \pm 3 bulan. Bibit ayam yang dibeli tidak diperhatikan sudah divaksin atau belum, kelompok juga tidak melakukan vaksin, sehingga menjadi penyebab kematian bibit ayam cukup tinggi (20-30\%) diawal pemeliharaan.

Ayam diberi pakan toko (harganya Rp. 9.000Rp. 10.000/kg) dan jagung (harganya Rp. 6.000/kg). Setiap produksi membutuhkan biaya pakan \pm Rp. 550.000-Rp.750.000. Pakan toko diberi sampai ayam berumur \pm 1 bulan, selanjutnya pakan berupa kombinasi pakan toko dan jagung, yang diberikan secara bergantian sehari 3 kali (pagi, siang, dan sore). Kelompok tidak mengatur banyaknya pakan berdasarkan umur sehingga memungkinkan tidak tercukupi kebutuhan nutrisi (ayam kurang sehat dan berat kurang) atau pakan berlebih (pemborosan). Disamping itu jagung sebagai pakan alternatif kurang menjamin tercukupinya nutrisi ayam, disebabkan kelompok belum mempunyai pengetahuan dan ketrampilan membuat ransum ayam.

Ayam dipelihara dalam kandang atau dibiarkan di pekarangan. Kandang berukuran 3-4 x 2-3 x 2,5 m (p $x 1 \times$ t), beratap seng, berlantai tanah, dan berdinding bambu. Sebagian besar kandang kondisinya rusak (dinding telah lapuk), namun tidak diperbaiki karena hasil penjualan tidak mencukupi. Kandang untuk pemeliharaan dan peralatan makan dan minum seadanya, dimana kebersihannya kurang diperhatikan (tidak dibersihkan sebelum atau sesudah penggunaan). Dalam kandang ditempatkan peralatan makan dan minum ayam namun jumlahnya terbatas (rata-rata tersedia1 tempat minum dan 2 tempat makan). Kondisi ini menyebabkan makanan dan minuman yang disediakan terbatas sehingga ayam dapat mengalami kekurangan air dan nutrisi.

Kandang yang tidak bersih dapat menjadi sarang kuman atau kutu yang berpotensi menyebabkan penyakit pada ayam, demikian juga bila peralatan makan dan minum ayam tidak bersih. Penyakit pilek biasa menyerang saat memasuki musim hujan yang dapat dipicu oleh peralatan (makan dan minum) dan kandang yang tidak bersih.

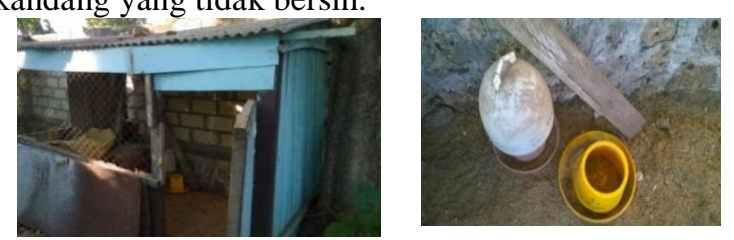

Gambar.2. Kondisi Kandang Ayam Rusak dan Tidak Bersih, Peralatan Makan/Minum Kotor 


\section{Tahapan Kegiatan}

\section{METODE PELAKSANAAN}

Berdasarkan solusi yang ditawarkan dan luaran yang dihasikan, dibuat rencana kegiatan yang meliputi:

1. Sosialisasi: Dilakukan pada awal kegiatan untuk memberikan informasi kegiatan yang akan dilakupan pada kelompok Inaie dan Berkat.

2. Persiapan: Dilakukan untuk menentukan koordinasi antara anggota tim dengan kelompok belajar. Koordinasi dilakukan untuk mendiskusikan waktu kegiatan dan bagaimana pelaksanaan kegiatan. Juga dilakukan persiapan alat dan bahan.

3. Pelaksanaan kegiatan yang meliputi:

a. Pembuatan kandang ayam model box berukuran 4 x $3 \times 2 \mathrm{~m}(\mathrm{p} \times 1 \times \mathrm{t})$, dindingnya dari bambu dan beratap seng, sebanyak 2 kandang.

b. Pembuatan kolam ikan secara permanen dari semen berukuran $3 \times 2 \times 0,5 \mathrm{~m}(\mathrm{p} \times 1 \times \mathrm{t})$ sebanyak 2 buah.

c. Pembuatan pakan ikan dari dedak halus, tepung kedelai, tepung terigu, tepung ikan, dan bahan tambahan lainnya (vitamin dan mineral). Metode sederhana membuat pakan adalah metode kuadratik yang didasakan pada pembagian bahan pakan menurut kandungan protein yaitu bahan baku mengandung $20 \%$ protein atau bahan baku yang kandungan proteinnya $>20 \%$ (Mahyuddin, 2008). Kegiatan menghasilkan pedoman membuat pakan ikan; produk berupa pakan ikan; dan peralatan membuat pakan ikan.

d. Pengaturan jumlah dan waktu pemberian pakan ikan. Kegiatan menghasilkan pedoman pemberian pakan ikan lele dan peralatan mengukur pakan.

e. Pembuatan ransum ayam dari jagung halus, dedak, dan tepung kedelai. Kegiatan menghasilkan pedoman pembuatan ransum ayam dan produk berupa ransum.

f. Pengaturan pemberian pakan dan ransum ayam, menghasilkan pedoman pemberian ransum ayam dan peralatan mengukur pakan dan ransum.

g. Pengendalian penyakit ngorok dan pilek pada ayam melalui vaksinasi, kebersihan kandang, tempat makan dan minum, dan pengobatan. Kegiatan menghasilkan pedoman dan jadwal pengendalian penyakit dan hama pada ayam.

h. Pembuatan demplot:

- Lokasi untuk kolam ikan dari semen disiapkan, kemudian dibangun kolam di permukaan tanah. Pupuk kandang dimasukkan dalam kolam, kemudian dibiarkan \pm 1 minggu untuk menunjang tersedianya pakan alami. Bibit ikan lele yang telah disteril dimasukkan ke dalam kolam. Kegiatan pemeliharaan diatur melalui manajemen makanan, pengendalian penyakit, dan jadwal kegiatan. Kegiatan menghasilkan pedoman budidaya ikan lele.

- Lokasi untuk demplot kandang ayam disiapkan, dan dibuat kandang ayam. Dalam kandang disiapkan tempat dan minum. Pemeliharaan ayam memperhatikan pakan/ ransum dan pengendalian penyakit. Kegiatan pemeliharaan diatur melalui manajemen makanan, pengendalian penyakit, dan jadwal kegiatan. Kegiatan menghasilkan pedoman beternak ayam dan pedoman pemberian pakan.

4. Monitoring/evaluasi: Dilakukan setiap saat, sejak dimulai kegiatan hingga selesai. Tingkat pengetahuan dan keterampilan sasaran akan diuji secara tidak resmi pada saat berlangsung dan akhir kegiatan.

5. Laporan akhir dan publikasi ilmiah: Laporan akhir dibuat untuk pertanggungjawaban pelaksanaan kegiatan. Publikasi ilmiah untuk menyebarluaskan hasil kegiatan.

\section{Metode dan Prosedur Pembelajaran}

Penerapan solusi diatas dilaksanakan melalui metode dan prosedur pembelajaran:

1. Metode: Ceramah/diskusi: menyampaikan pengetahuan secara lisan kepada para peserta. Peserta aktif melalui tanya jawab dan diskusi.

Prosedur: Materi (berupa handout dan leaflet) disiapkan oleh pemateri satu minggu sebelum kegiatan untuk dipelajari. Pemateri yang mempunyai kepakaran terkait materi, dalam pembelajran terjadi tanya, jawab, dan diskusi.

2. Metode: Demontrasi adalah memperagakan barang dan urutan suatu kegiatan, secara langsung atau menggunakan media pengajaran yang relevan dengan pokok bahasan/materi yang sedang disajikan.

Prosedur: Tim menyiapkan alat/bahan yang dibutuhkan untuk membuat produk, alat, atau model/desain. Cara membuat produk, alat, atau model/desain diberikan sehingga peserta lebih mudah memahami. Pemateri meragakan cara membuat produk dan alat serta aplikasinya di lapangan.

3. Metode: Praktik adalah kelompok dilatih melakukan suatu proses. Praktik mungkin lebih dari satu kali agar kelompok lebih terampil.

Prosedur: Tim menyiapkan alat, bahan, prosedur, juga tempat kegiatan untuk percobaan. Sebelum percobaan peserta mempelajari prosedur kerja. Peserta dibagi dalam kelompok (3-4 orang), dan tahap-tahap prosedur dilakukan secara kelompok, setiap kelompok dapat mengulang tahap-tahap agar terampil.

4. Metode: Rancang bangun adalah mempelajaran melalui pembuatan alat dan cara penggunaannya. Peserta dilibatkan secara aktif merancang alat. Prosedur: Tim dan peserta menentukan tempat merancang alat. Peralatan, bahan, dan prosedur 
disiapkan. Sebelumnya pemateri menjelaskan bagaimana alat dirancang dan pengunaannya. Kelompok merangcang alat berdasarkan pedoman dan bimbingan dari pemateri.

5. Metode: Demplot dibuat berdasarkan kegiatan praktik, merupakan media belajar bagi kelompok beternak bersama di lokasi yang disediakan.

Praktik: Tim pelaksana dan kelompok menentukan lokasi demplot kolam dan kandang. Tim menyiapkan alat, bahan, bibit ikan/ayam, atau hasil praktik untuk diaplikasikan di kolam dan kandang ayam; peserta menyiapkan demplot.

6. Metode: Pendampingan untuk membantu/ membimbing kelompok dalam menerapkan materi/Ipteks yang telah dipelajari.

Prosedur: Tim menyusun jadwal pendamping, membuat catatan pada logbook, serta melakukan diskusi dengan kelompok belajar berkaitan penerapan Ipteks.

\section{Partisipasi dan Evaluasi Mitra}

Pelaksanan kegiatan akan berhasil bila mitra berpartisipasi. Kelompok berkeinginan mempunyai pengetahuan, keterampilan, dan teknologi, yang terlihat dari partisipasi kelompok. Partisipasi kelompok berupa menyediakan sebagian beberapa bahan (bambu, bibit ikan, bahan membuat pakan lele, dan bahan ransum ransum ayam); waktu; tenaga (membantu membuat kandang dan kolam); mengikuti pembelajaran secara aktif; menerapkan teknologi;

bersedia mengembangkan/menyebarluaskan teknologi yang diterima; dan menyediakan tempat untuk pelaksanaan kegiatan dan demplot.

Partisipasi kelompok belajar diamati dan diuji pada:

1. Prakegiatan: mengukur pemahaman kelompok belajar melalui tanya jawab mengenai beternak ayam dan ikan.

2. Proses kegiatan:

- Partisipasi kelompok menyediakan tempat meletakkan bahan dan alat, lokasi kandang dan kolam, menerima dan menerapkan teknologi, dan lahan demplot sebagai model beternak ayam dan ikan.

- Pengetahuan dan ketrampilan menjelaskan beternak ikan lele/ayam pedaging, membuat ransum ayam, pengendalian penyakit pada ikan dan ayam, menjaga kebersihan kolam, kandang, dan peralatan, manajemen usaha secara sederhana.

3. Monitoring dan pendampingan, untuk melihat dampak terhadap kelompok.

Setelah kegiatan kelompok terus menerapkan materi dan teknologi yang diperoleh. Demplot yang menjadi contoh pernah dikunjungi kelompok lain yang tertarik dan mau mengadopsi teknologi. Kelompok Inaie dan Berkat merespon dengan berbagi pengetahuan dan teknologi.

\section{HASIL DAN PEMBAHASAN}

Tim pelaksana memberikan penjelasan ke kelompok Kelompok Inaie dan Berkat mengenai gambaran kegiatan ipteks yang akan dilaksanakan. Gambaran yang dinformasikan dan diskusi tim pelaksana dan kelompok maka kegiatan-kegiatan yang akan dilakukan yaitu beternak ayam broiler; ransum ayam; pengendalian penyakit pada ayam; beternak ikan lele; pengendalian penyakit pada ikan lele; pakan ikan buatan sendiri; manajemen usahatani beternak ayam dan ikan lele; pembukuan sederhana usaha; demplot beternak ikan lele; dan demplot beternak ayam broiler. Berdasarkan kegiatan-kegiatan tersebut maka materi kegiatan seperti tertera pada Tabel 1.

Tabel 1. Pemateri/Narasumber dan Materi Kegiatan

\begin{tabular}{|l|l|}
\hline \multicolumn{1}{|c|}{ Nama } & \multicolumn{1}{|c|}{$\begin{array}{c}\text { Materi/Praktik sebagai Solusi } \\
\text { Masalah }\end{array}$} \\
\hline $\begin{array}{l}\text { Marsema Kaka } \\
\text { Mone, SP., M.Sc } \\
\text { Lena Walunguru, } \\
\text { SP., M.Si }\end{array}$ & $\begin{array}{l}\text { - Manajemen usahatani beternak } \\
\text { ayam dan ikan lele }\end{array}$ \\
& $\begin{array}{l}\text { Model pembukuan sederhana: } \\
\text { usaha beternak ayam, } \\
\text { pembesaran lele }\end{array}$ \\
\hline Narasumber 1 & - Beternak ayam broiler pedaging \\
\hline Nara sumber 2 & - Ransum ayam \\
& - Pengendalian hama dan penyakit \\
& pada ayam \\
\hline Nara sumber 3 & $\begin{array}{l}\text { Budidaya ikan lele } \\
\text { - Pengendalian penyakit ikan lele } \\
\text { - Pakan lele buatan sendiri }\end{array}$ \\
\hline
\end{tabular}

Selain itu, tim dan kelompok mendiskusikan waktu pelaksanaan, tahapan kegiatan, dan lokasi demplot. Waktu pelaksanaan direncanakan dimulai pada bulan Maret atau April 2018 untuk persiapan bangunan (kandang dan bak untuk kolam lele) alat, bahan, dan demplot. Pelaksanaan kegiatan direncankan pada bulan Juni 2018. Tahapan pelaksanaan meliputi persiapan kolam, kandang, alat dan bahan, persiapan demplot, dan pelaksanaan. Lokasi demplot ditentukan di lahan milik ketua kelompok Berkat untuk kandang ayam (karena teduh dan tersedia sumur) dan kandang ayam (agak jauh dari rumah penduduk lainnya) dan anggota kelompok untuk kolam lele (dekat dengan sumber air dari sungai).

Persiapan-persiapan yang dilakukan dan hasilnya yaitu:

1. Pembuatan kandang ayam dan kolam ikan

- Kolam ikan yang dibangun (Gambar 5.1) adalah kolam ikan permanen dari semen dengan 
sebanyak dua bak dengan ukuran masing-masing $5 \mathrm{x}$ $3 \times 1 \mathrm{~m}$ dan $5 \times 3,5 \times 1$ ( $\mathrm{p} \times 1 \times \mathrm{t})$.

- Kandang ayam

Kandang ayam yang semula direncanakam dibangun berukuran $8 \times 5 \times 3 \mathrm{~m}(\mathrm{p} \times 1 \times \mathrm{t})$, berdinding bambu dan beratap seng (Gambar 5.2). Kelompok mengusulkan lantai kandang dicor, $1 \mathrm{~m}$ tinggi kandang dari lanti dari batako dan sisanya dari kawat ram. Kandang dirancang pada bagian luar sebagian dipasangi terpal karena saat itu pada pagi sampai siang angin bertiup kencang dan sore/malam hari sampai menjelang suhu udara dingin.

Kelompok berpartisipasi aktif dalam pembangunan kolam ikan dan kandang ayam.
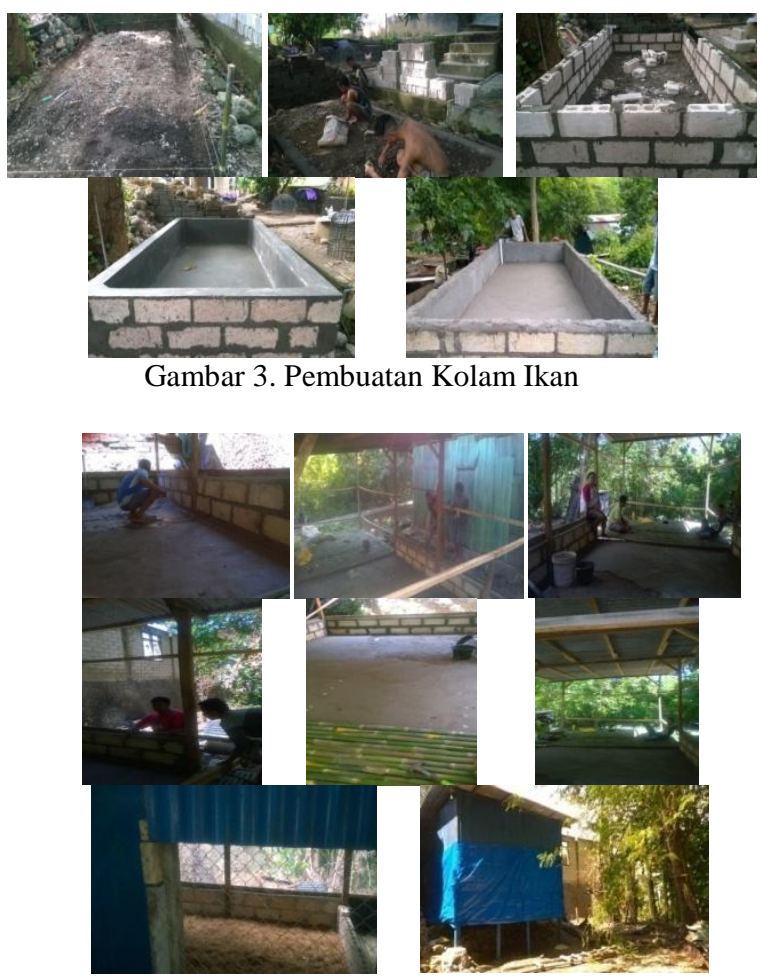

Gambar 4. Pembuatan Kandang Ayam

Hasil dari tahapan ini adalah dibangunnya kolam ikan lele sebanyak dua bak masing-masing berukuran $5 \times 3 \times 1 \mathrm{~m}$ dan $5 \times 2,5 \times 1(\mathrm{p} \times 1 \times \mathrm{t})$ dan kandang ayam berukuran $8 \times 5 \times 3 \mathrm{~m}(\mathrm{p} \times 1 \times \mathrm{t})$. Diharapkan kelompok selanjutkan memanfaatkan agar lebih mendukung usaha yang dijalankan.

2. Pengadaan peralatan dan bahan: Dilakukan agar saat pelaksanaan alat dan bahan yang dibutuhkan sudah tersedia sehingga memudahkan pelaksanaan kegiatan. Persiapan alat dan bahan untuk:

a. Beternak lele berupa peralaatan dan bahan untuk membuat pakan buatan sendiri dan pakan toko, waring penutup kolam, timbangan, dan jarring ikan (Gambar 5).

b. Beternak ayam berupa peralatan makan dan minum, alat dan bahan pencegah penyakit, penerang kandang, dan pakan ayam (Gambar $6)$.

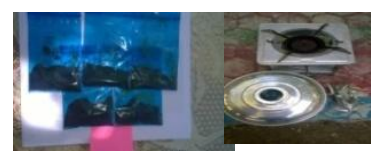

a

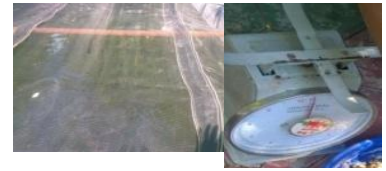

e

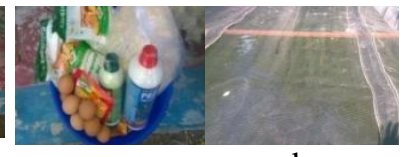

c

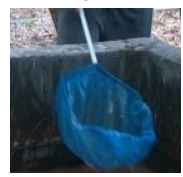

g
Gambar 5. Bahan Pencegah Penyakit Lele (a)

Peralatan dan Bahan Pakan Lele

(b dan c), Waring Mencegah Hama

Lele (d), Timbangan untuk Ukur

Pakan Ikan (e), dan Jaring Ikan (f)

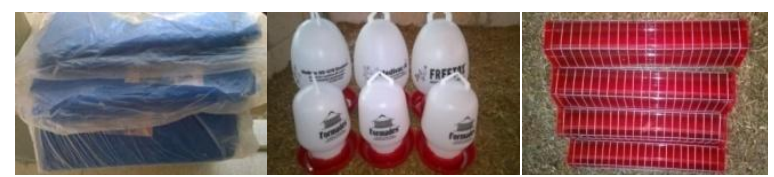

A
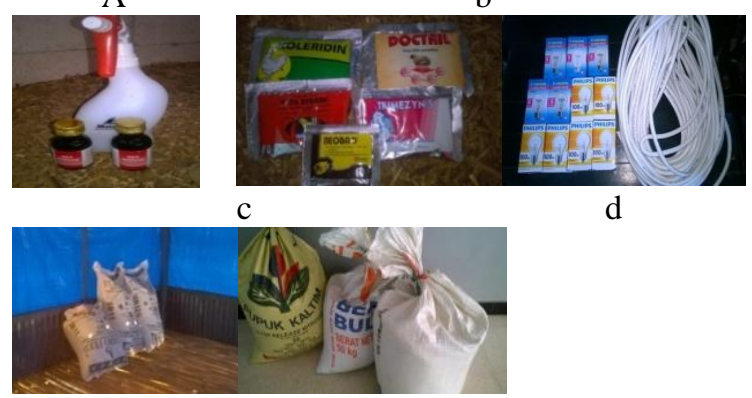

e

Gambar 6. Terpal Penutup Dinding (Mengurangi

Angin dan Dingin dalam Kandang (a),

Peralatan Makan Minum (b), Alat dan

Obat Pencegah Penyakit (c), Penerang

Kandang (d), dan Pakan dan Ransum

Ayam (e)

Hasil dari pelaksanaan tahapan ini adalah peralatan dan bahan penunjang yang lebih memadai berdampak pada keberlangsungan usahayang baik yaitu meningkatnya kapasitas ternak yang dipelihara, meminimalkan serangan penyakit pad ternak, dan mengurangi biaya produksi terutama biaya untuk pakan.

3. Persiapan demplot kolam ikan dan kandang ayam (Gambar 7 dan 8).

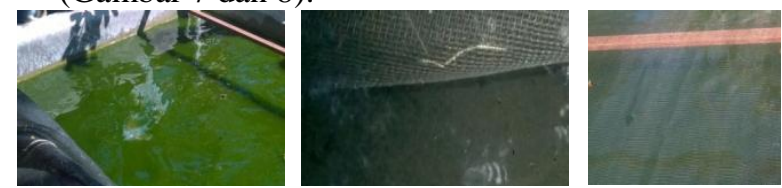

Gambar 7. Persiapan Demplot Kandang Kolam Ikan 


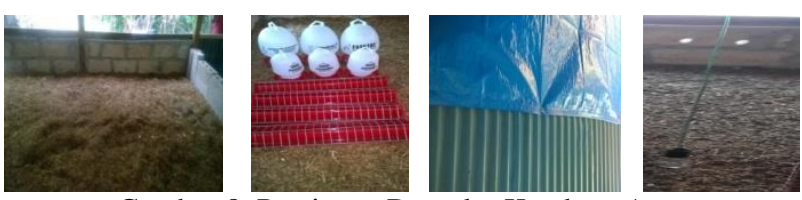

Gambar 8. Persiapan Demplot Kandang Ayam

Kandang ayam yang telah dibangun untuk demplot sebelum digunakan dipersiapkan yaitu lantainya (dicor semen) dilapisi dengan serbuk kayu tujuannya agar bibit ayam lebih hangat juga memudahkan dalam pembersihan lantai. Lampu dan peralatan makan dan minum dipasang pada sejumlah titik. Terdapat 8 titik lampu, 8 tempat makan, dan 8 tempat minum. Bibit ayam sebanyak 100 ekor sebelum dikandangnya divaksin (bibit ayam dibeli yang telah divaksin).

Kolam ikan disi air, pengisian air satu minggu atau sampai air telah berwarna hijau sebelum bibit lele dimasukkan ke dalam bak. Satu kolam disi dengan 2.000 bibit ikan lele dan satunya sebanyak 1.500 bibit ikan lele.

Kelompok ternak berpartisipasi aktif dalam mempersiapkan demplot kandang ayam dan kolam ikan. Partisipasi kelompok yaitu membawa serbuk gergaji dan menaburkan di lantai kandang serta memasang lampu dan peralatan makan/minum. Terpal dipasang pada sebagian dinding bagian luar. Pemasangan terpal bunanya untuk mengurangi angin yang masuk ke dalam kandang yang pada saat itu bertiap kencang pada siang hari. Angin yang bertiap kencang akan berpengaruh pada bibit penyakit yang terbawa angin, dengan adanya pemasangan terpal diharapkan meminilkan bibit penyakit yang terbawa angin. Selai itu, pemasangan terpal berfungsi agar udara dalam kandang tetap hangat karena saat malam udara cukup dingin dimana bibit ayam (berumur 1-2 minggu) rentan terhadap suhu dingin yang dapat menyebabkan kematian bibit.

Kegiatan telah dilaksanakan pada tanggal 30 Juni 2018. Metode pelaksanaan kegiatan berupa ceramah, diskusi, demonstrasi, dan praktik dilakukan ruang terbuka dan demplot (Gambar 9; 10; 11; dan 12).

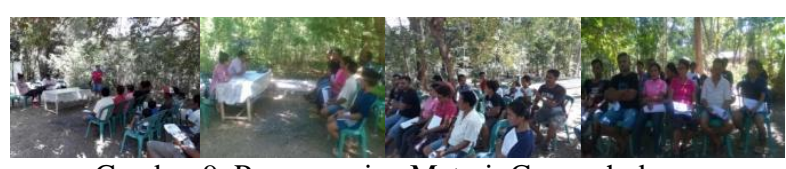

Gambar 9. Penyampaian Materi: Ceramah dan Diskusi

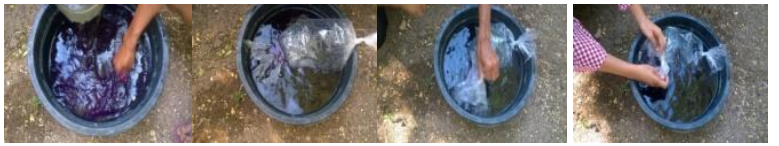

Gambar 10. Praktik Pengendalian Hama dan Penyakit Ikan: Perendaman Bibit Lele dalam Larutan PK

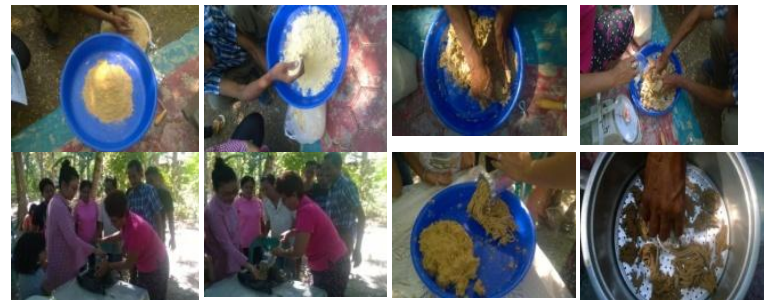

Gambar 11. Praktik Pembuatan Pakan Ikan
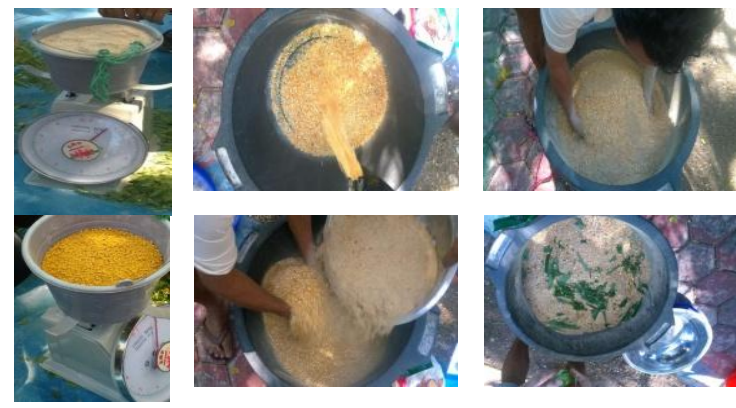

Gambar 12. Praktik Membuat Ransum Ayam

Kegiatan selanjutnya adalah di demplot kolam lele (Gambar 13) dan kandang ayam (Gambar 14). Di demplot kolam lele kelompok memasukkan bibit lele ke dalam dua kolam (masing-masing kolam sebanyak 2.000 ekor) setelah diberi perlakuan pengendalian hama dan penyakit yaitu bibit lele direndam dengan air yang telah diberi PK selama \pm 30 menit. Selanjutnya bibit lele diberi pakan toko sesuai pedoman pemberian pakan yaitu jumlah pakan yang diberikan disesuaikan dengan berat ikan dalam kolam.

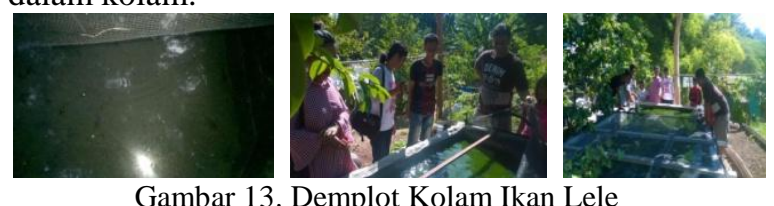

Di demplot kamdang ayam kelompok ternak memasukkan bibit ayam sebanyak 100 ekor. Sebelummnya kelompok telah membersihkan dan mensterilkan kandang ayam dan telah menempatka tempat makan dan minum serta kandang dipasang lampu penerang pada 8 titik. Dinding kandang bagian luar sebagian dipasang terpal untuk mengurangi angin yang masuk dalam kandang dan saat meminimlakna udara dingan yang masuk dalam kandang agar udara tetap hangat. Bibit ayam diberi pakan toklo berdasarkan pedoman maka setiap pemberian pakan kelompok menimbang pakan berdasarkan umur bibit. Untuk pemeliharaan selanjutnya berupa pemberian pakan dan minum, membersihkan kandang, dan peralatan makan, serta pemberian obat untuk pengendalian penyakit. 

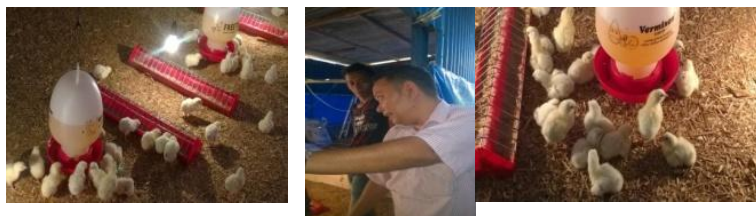

Gambar 14. Demplot Kandang Ayam

Hasil kegiatan adalah bertambahnya pengetahuan dan ketrampilan anggota kelompok dalam berusaha ternak ikan lele dan ayam broiler/pedaging dengan meniru dan mengembangkan model yang terapkan pada demplot ikan lele dan ayam broiler. Hal ini terlihat rendaknya tingkat kematian bibit lele maupun anak ayam. Ratarata pada kedua kolam bibit lele yang mati pada minggu pertama yaitu 12-15 ekor dari 2.000 ekor, , minggu kedua sebanyak 5-7 ekor, dan minggu selanjutnya tidak ada lele yang mati. Disamping itu dengan adanya pengaturan pakan kelompok merasa cukup mengurangi pakan yang terbuang, mengurangi biaya pakan lele karena ada pakan buatan sendiri, kualitas air kolam lebih baik, dan tidak ada lele yang terserang penyakit. Kandang ayam, peralatan minum dan makan yang bersih, pencegahan penyakit melalui obat yang diberi melalui minuman juga didukung oleh tersedianya makan dan minum, serta kondisi kandang yang hangat dan sirkulasi udara yang lancar berdampak pada tingkat kematian anak ayam yang rendah. Dari 100 ekor bibit ayam yang dipelihara yang mati pada minggu pertama sebanyak 4 ekor, minggu kedua dua ekor, dan minggu berikutnya tidak ada yang mati, hal ini berarti tinggkat kematian ayam hanya $6 \%$. Kelompok juga melakukan manajemen usaha namun pencatatan/pembukuan usaha masih kurang disiplin.

Kegiatan yang dilaksanakan mendapat respon yang positif dari kelompok, karena pengetahuan dan teknologi yang diperoleh memang dibutuhkan untuk memecahkan masalah-masalah dalam beternak ikan lele dan ayam. Penerapan pengetahuan dan teknologi dalam usaha beternak diharapkan berdampak positif dalam meningkatkan hasil sehingga pendapatan meningkat. Respon positif terlihat dari kesediaan kelompok menyediakan lokasi penyampaian teori, praktik, dan demplot kolam ikan dan kandang ayam, serta membangun kolam dan kandang. Kelompok antusias menerima dan menerapkan teknologi dalam kegiatan, juga berpartisipasi aktif selama kegiatan maupun selama pendampingan.

Keberhasilan kegiatan tidak lepas dari partisipasi aktif kelompok terlihat pada keaktifan dalam diskusi, melakukan praktik, dan keberlanjutan menerapkan teknolgi setelah kegiatan. Evaluasi keaktifan peserta diukur dari beberapa indikator yaitu:

\section{Kehadiran}

Jumlah total anggota kelompok 18 orang, namun dari jumlah tersebut anggota yang aktif 12 orang.
Saat kegiatan semua anggota aktif hadir, jumlah kehadiran ini sama pada semua kegiatan yang dilakukan saat penyuluhan, praktik, dan di demplot.

2. Partisipasi peserta

Partisipasi peserta diukur dari keaktifan dalam berdiskusi dan melakukan praktik. Saat penyuluhan peserta aktif bertanya dan mendiskusikan masalah-masalah yang dihadapi dalam beternak ayam dan beterkan ikan lele, juga aktif melakukan persiapan menyediakan alat, bahan, dan lokasi. Saat praktik peserta mampu melakukan sendiri setelah demonstrasi oleh pemateri.

3. Materi kegiatan

Penyajian materi/penyuluhan diikuti demostrasi dan praktik untuk memudahkan peserta memahami materi dan mampu secara mandiri melakukan teknologi yang diperoleh.

4. Keberlanjutan penerapan teknologi

Setelah kegiatan kelompok terus menerapkan materi dan teknologi yang diperoleh. Demplot yang menjadi contoh diharapkan memberi motivasi bagi kelompok atau peternak lainnya. Kelompok ternak Inaie dan Berkat merespon dengan berbagi pengetahuan dan teknologi

\section{SIMPULAN DAN SARAN \\ Simpulan}

Kegiatan pengabdian yang telah dilaksanakan membantu kelompok dalam menghadapi masalahmasalah dalam beternak ikan lele maupun ayam broiler yang terlihat dari meningkatnya hasil produksi karena adanyanya peningkatan pengetahuan dan ketrampilan juga didukung sarana dan prasarana yang lebih memadai. Kelompok menerapkan dengan baik apa yang diperoleh sehingga usaha produkstif secara ekonomi.

Saran

Kelompok ternak Inaie dan Berkat harus tetap mempunyai keinginan yang kuat untuk memajukan usahanya agar produktif secara ekonomi untuk pengetahuan dan ketrampilan yang diperoleh terus dikembangkan dan diterapkan dalam usaha beternak ikan lele dan ayam pedaging.

\section{DAFTAR PUSTAKA}

[1] Mahyuddin, K. 2008. Agribisnis Lele. Penebar Swadaya. Jakarta.

[2] Nataamijaya, A. G. 2002. Beberapa Penyakit pada Ayam. Makalah. Badan Penelitian dan Pengembangan Pertanian. Depatemen Pertanian Palembang.

[3] Rasyaf, M. 2011. Panduan Beternak Ayam Pedaging. Penebar Swadaya. Jakarta.

[4] Saparinto, C. 2013. Budidaya Ikan. Penebar Swadaya. Jakarta.

[5] Kustiasari, T. and Gemaputri, A.A., 2016. DESAIN KOMUNIKASI PROMOSI PRODUK BABY FISH SISTEM MINA PADI DI DESA WISATA ORGANIC LOMBOK KULON, KECAMATAN WONOSARI, KABUPATEN BONDOWOSO. $J$ Dinamika, 1(2). 